\title{
Article \\ Taro (Colocasia esculenta (L.) Schott) Yields and Soil Chemical Properties Were Improved by Row-Surface Straw Mulching
}

\author{
Zihui Zhu ${ }^{1,+}$, Jiayu Qian ${ }^{1,+}{ }^{\text {, }}$ Yongxian Zhang ${ }^{1,+}{ }^{+}$, Hao Zhang ${ }^{1,+}$, Haibo Dai ${ }^{1}$, Zhiping Zhang ${ }^{1}($, \\ Minmin Miao ${ }^{1,2, *}$ and Jiezeng Jiang ${ }^{1,2, *}$
}

1 College of Horticulture and Plant Protection, Yangzhou University, Yangzhou 225009, China; mx120190616@yzu.edu.cn (Z.Z.); mx120190620@yzu.edu.cn (J.Q.); mx120180598@yzu.edu.cn (Y.Z.); mz120180959@yzu.edu.cn (H.Z.); dx120180088@yzu.edu.cn (H.D.); zhangzp@yzu.edu.cn (Z.Z.)

2 Joint International Research Laboratory of Agriculture, College of Horticulture and Plant Protection, Yangzhou University, Yangzhou 225009, China

* Correspondence: mmmiao@yzu.edu.cn (M.M.); jzjiang@yzu.edu.cn (J.J.); Tel.: +86-0514-87979346 (M.M.); +86-0514-87979394 (J.J.); Fax: +86-0514-87347537 (M.M.)

+ These authors contributed equally to this work.

Citation: Zhu, Z.; Qian, J.; Zhang, Y.; Zhang, H.; Dai, H.; Zhang, Z.; Miao, M.; Jiang, J. Taro (Colocasia esculenta (L.) Schott) Yields and Soil Chemical Properties Were Improved by Row-Surface Straw Mulching. Agronomy 2022, 12, 645. https:// doi.org/10.3390/agronomy12030645

Academic Editors: Othmane Merah, Purushothaman Chirakkuzhyil Abhilash, Magdi T. Abdelhamid, Hailin Zhang and Bachar Zebib

Received: 12 February 2022

Accepted: 4 March 2022

Published: 6 March 2022

Publisher's Note: MDPI stays neutral with regard to jurisdictional claims in published maps and institutional affiliations.

Copyright: (C) 2022 by the authors. Licensee MDPI, Basel, Switzerland. This article is an open access article distributed under the terms and conditions of the Creative Commons Attribution (CC BY) license (https:// creativecommons.org/licenses/by/ $4.0 /)$

\begin{abstract}
The rational use of a large amount of straw produced from grain fields is an important issue in major grain-producing areas. On the other hand, due to the long-term preferential applications of chemical fertilizers, soil organic carbon (SOC) content, soil fertility and organic matter levels have decreased, and the soil physical-chemical properties have deteriorated in protected agricultural facilities. In this study, a wet crop, taro (Colocasia esculenta (L.) Schott) and the straw of two main crops [wheat (Triticum aestivum L.) and rice (Oryza sativa L.)] were selected to investigate the effect of row-surface straw mulching on taro yields and soil chemical properties. The results showed that nearly all wheat straw and $74 \%$ of rice straw decomposed in one season under wet conditions. Straw mulching significantly increased the taro yield, increased the levels of SOC, soil rapid available nitrogen, phosphorus and potassium, and improved the activities of sucrase and phosphatase in the soil. We conclude that row-surface straw mulching t of wet crops could not only improve the soil properties and crop yields in the protected facility but could also consume considerable straw (wheat: $14,250 \mathrm{~kg} / \mathrm{ha}$, rice: $111,00 \mathrm{~kg} / \mathrm{ha}$ ), and the method applied in other areas with similar conditions.
\end{abstract}

Keywords: straw mulching; taro; wettish cultivation; soil nutrient; soil enzyme

\section{Introduction}

In recent years, protected facilities used in the vegetable production have developed rapidly and have greatly met the needs of urban and rural residents and brought great economic and social benefits in China and other countries [1]. For economic reasons, farmers tend to apply chemical fertilizers excessively to improve vegetable yields to meet market demands [2,3]; about 550-600 kg/ha fertilizer have been applied in the field in China [3]. In addition, the lack of application of organic fertilizer and unreasonable irrigation methods have resulted in serious imbalances in the soil nitrogen $(\mathrm{N})$, phosphorus $(\mathrm{P})$ and potassium (K) nutrient ratios, deterioration of soil physical and chemical properties, soil degradation and other problems [4]. This soil degradation has seriously restricted the development of the facility vegetable industry, which affects both the yields and quality of vegetables [5].

On the other hand, wheat (Triticum aestivum L.) and rice (Oryza sativa L.) are two main food crops in the word [6]. Approximately 1129 million tons of straw were produced from rice and wheat crops in 2019 [7,8]. In the past, after farmers had retained sufficient straw for cooking, most of the remaining straw was burned in the field locally, which led to serious air pollution $[9,10]$. As a result, the government issued rules and regulations to prohibit farmers straw burning, which has led to a serious resource oversupply of various 
straw types [11]. Using rice and wheat straw to produce biochar is an alternative way of consuming these plant residues [12]. However, processing capacity is limited in most developing countries [13]. To solve this problem and reach the goals of recycling waste and protecting the environment, the government has encouraged farmers to return straw to the field or to use straw as substrate for edible fungal production [14]. Currently, returning straw to field is a time-saving and labor-saving method for straw consumption, and may be counterproductive if not conducted properly. In general, straw return benefits the soil since it is rich in nutrients. However, it may increase levels of soil $\mathrm{N}$ fixation in the short term, resulting in $\mathrm{N}$ deficiency and yield decline [15]. In addition, substances such as organic acids that form during the decomposition of straw have negative effects on crop growth. Furthermore, the aggravation of soil-borne diseases is caused by pathogenic bacteria introduced to the soil due to returning straw [16]. Therefore, we need to provide farmers with knowledge to make rational use of their existing natural resources.

Taro (Colocasia esculenta (L.) Schott) is a perennial herb belonging to the Araceae [17], grown in warm and humid swamps such as those in China, Malaysia and the Indian Peninsula. Since it has evolved from aquatic plants, during the growth period a humid environment is required in both the soil and air. Taro is an important cash crop, and its petioles, flowers and stems can be used as both foods or medicines with high nutritional or medicinal value [18]. Because taro starch particles are small, easy to digest, and suitable for all ages, they are increasingly favored by various consumers in the world [19]. Nakajima et al. [20] found that the decomposition rates of straw were accelerated under conditions of high temperature and humidity. Taro is a wet vegetable, so straw return to taro fields may be favorable for straw decomposition and nutrient release. Therefore, this study explored the effects of different straw mulching treatments on the taro yields, soil nutrients and enzyme activities of taro fields.

\section{Materials and Methods}

\subsection{Site Description}

A wheat straw mulching test was conducted in the Hanjiang District, Yangzhou City, $\left(32^{\circ} 22^{\prime} \mathrm{N}, 119^{\circ} 24^{\prime} \mathrm{E}\right)$, and a rice straw mulching test was conducted in the Jintan District, Changzhou City $\left(31^{\circ} 45^{\prime} \mathrm{N}, 119^{\circ} 34^{\prime} \mathrm{E}\right)$ (Figure 1A). Both Hanjiang and Jintan District are located in Jiangsu Province and have a north subtropical humid monsoon climate, four distinct seasons, abundant rainfall and sufficient light. The annual average temperature in Hanjiang District is $15^{\circ} \mathrm{C}$, and the annual average precipitation is $1063.2 \mathrm{~mm}$; The frost-free period is 223 days. The annual precipitation in Jintan district is $1063.5 \mathrm{~mm}$, and the annual average temperature is $15.3^{\circ} \mathrm{C}$; The frost-free period is 228 days.

\subsection{Experimental Materials}

Jintan red taro, a popular cultivar grown in Jiangsu province, was used in this study. The straw of wheat and rice were collected from local farmers. The nutrient contents of the straw are listed in Table 1 . The types of fertilizers used in the experiment were $45 \%$ ternary compound fertilizer ( $\left.\mathrm{N}: \mathrm{P}_{2} \mathrm{O}_{5}: \mathrm{K}_{2} \mathrm{O}=15: 15: 15\right)$; urea $(\mathrm{N} \mathrm{46 \% )}$; and rape seed cake (organic matter $747.34 \mathrm{~g} / \mathrm{kg}, \mathrm{N} 56.74 \mathrm{~g} / \mathrm{kg}, \mathrm{P}_{2} \mathrm{O}_{5} 20.15 \mathrm{~g} / \mathrm{kg}, \mathrm{K}_{2} \mathrm{O} 13.95 \mathrm{~g} / \mathrm{kg}$ ).

Table 1. Nutrient content of dry wheat and rice straw.

\begin{tabular}{ccccc}
\hline Straw Type & $\begin{array}{c}\text { Total Nitrogen } \\
\mathbf{m g} / \mathbf{g}\end{array}$ & $\begin{array}{c}\text { Total Phosphorus } \\
\mathbf{~} \mathbf{g} / \mathbf{g}\end{array}$ & $\begin{array}{c}\text { Total Potassium } \\
\mathbf{~ m g / g}\end{array}$ & $\begin{array}{c}\text { Organic Carbon } \\
\mathbf{g} / \mathbf{k g}\end{array}$ \\
\hline Rice & 7.64 & 3.22 & 26.13 & 386.17 \\
Wheat & 4.43 & 4.52 & 24.73 & 430.78 \\
\hline
\end{tabular}


A

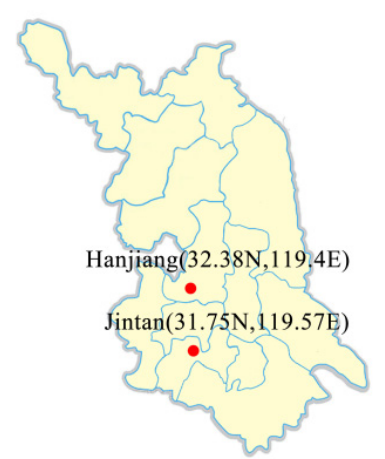

$\mathrm{C}$
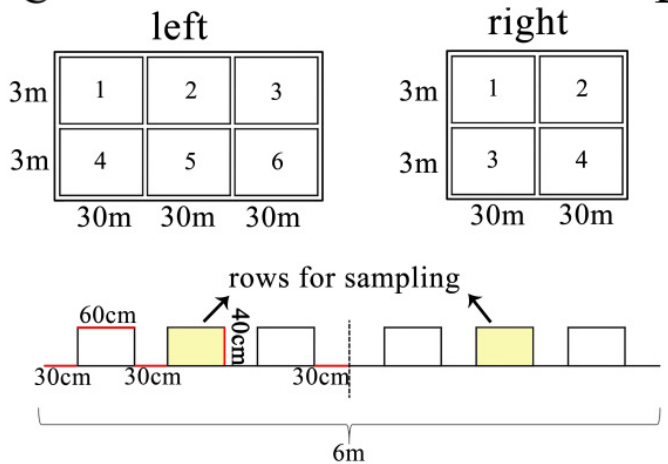

B

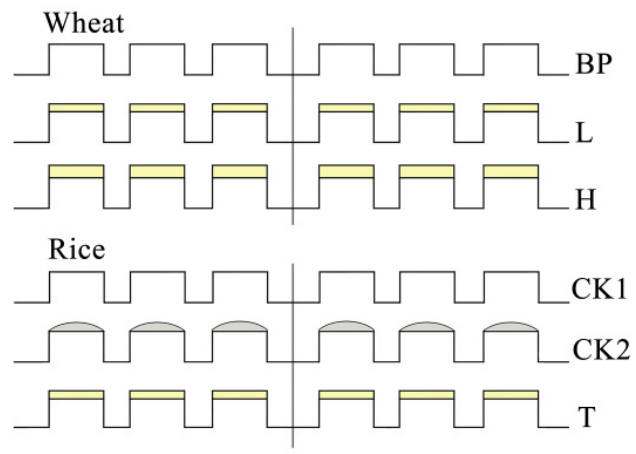

$\mathrm{D}$

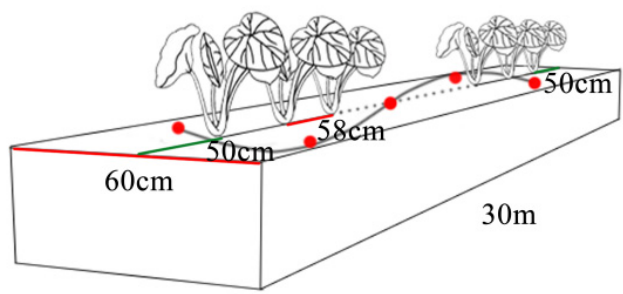

Figure 1. Experimental design. (A) Orientation of two test points in Jiangsu Province, China. (B) Treatments. Yellow indicates laying of straw, and gray indicates laying of film mulching. (C) Planting diagram of two experiments (only one block is shown for each experiment). In the wheat straw mulching experiment, plastic tunnels of $90 \mathrm{~m} \times 6 \mathrm{~m}$ were used. Five treatments (including control) were randomly arranged in one plastic tunnel as one repetition (left). In the rice straw mulching experiment, plastic tunnels of $60 \mathrm{~m} \times 6 \mathrm{~m}$ were used. Three treatments (including control) were randomly arranged (right). (D) Taro planting and soil sampling. BP: before planting; L: straw mulching 11,250 kg/ha; H: straw mulching 18,750 kg/ha; CK1: taro seedlings were directly planted in the rows without mulching; CK2: seedlings were covered with black mulching film; T: rice straw mulching at $15,000 \mathrm{~kg} / \mathrm{ha}$.

\section{Experimental Design and Treatments}

\subsection{Wheat Straw Mulching Experiment}

Two dosages and two sizes of straw mulching were designed in this experiment. Light mulching (L) evenly covered the row surface with wheat straw at $11,250 \mathrm{~kg} / \mathrm{ha}$, while heavy mulching $(\mathrm{H})$ evenly covered at $18,750 \mathrm{~kg} / \mathrm{ha}$. "Short straw" is the straw mechanically cut and baled during harvesting, with an average cutting size of approximately $10 \mathrm{~cm}$, while "long straw" received no treatment after harvesting. Thus, four combination treatments, (L, short), (L, length), (H, short) and (H, length) were performed in this study. No straw mulching was used as the control. (Figure 1B). Six plots were designed in a plastic tunnel and five treatments were randomly arranged in the six plots. Each plot had an area of $90 \mathrm{~m}^{2}$ and three rows for planting taro. To ensure the accuracy of the experiment, only the plants and the soil from the middle row were sampled. A randomized block trial was performed with three repetitions (Figure 1C). The planting rows were $30 \mathrm{~m}$ long and $60 \mathrm{~cm}$ wide, and the ditches were $30 \mathrm{~cm}$ wide (Figure 1C). Taro plants were transplanted with plant and row spacing of $58 \times 60 \mathrm{~cm}$. Fifty seedlings were planted in each row in one plot, equivalent to 33,333 plants/ha. To prevent the taro growth from being affected, $45 \mathrm{~cm}$ was left on both sides and $50 \mathrm{~cm}$ was left on the tops of both tunnels (Figure 1D).

On 5 May 2019, $150 \mathrm{~kg} /$ ha of ternary compound fertilizer, $525 \mathrm{~kg} / \mathrm{ha}$ of urea and $22.5 \mathrm{t} /$ ha of rape seed cake were applied as base fertilizer. The planting rows were prepared, and seedlings were transplanted on 19 May 2019. The straw was covered on the row surface 
immediately after planting. The straw was kept wet by daily watering (the soil water content was always above $80 \%$ ). One hundred-and-fifty $\mathrm{kg} / \mathrm{ha}$ of urea was spread over the row surface on 25 September 2019, and the taro was harvested on 4 December 2019 (Figure 2A). The remaining straw after harvest was collected, washed, dried and weighed to determine decomposition rates.

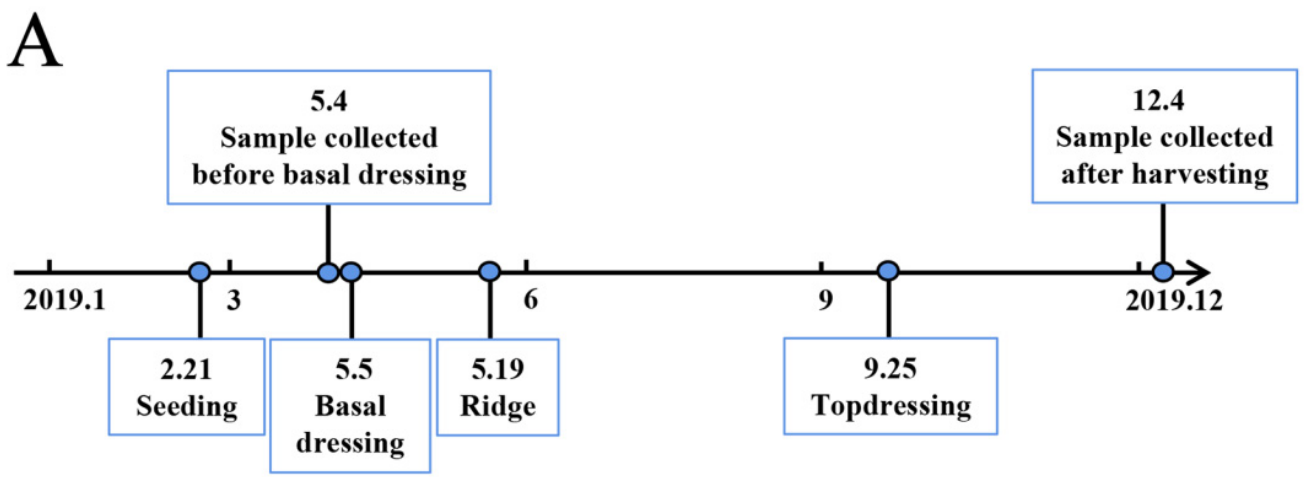

B

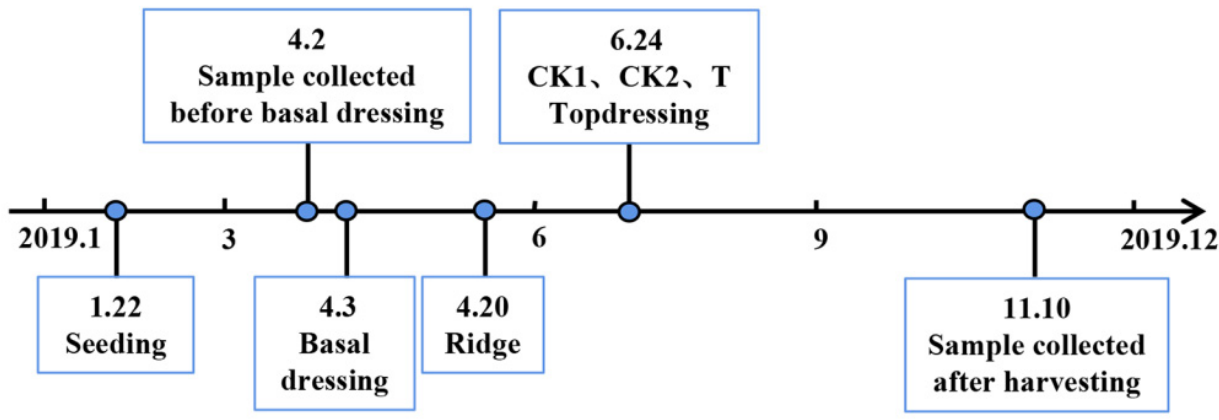

Figure 2. Time flow chart of the taro field management and sampling. (A) Wheat straw mulching experiment. (B) Rice straw mulching experiment.

Straw decomposition rate:

$$
S=\frac{A-B}{A} \times 100 \%
$$

where $A$ is the total amount of straw before experiment, $B$ is the remaining straw at the time of sampling, and $S$ is the straw decomposition rate.

\subsection{Rice Straw Mulching}

Three treatments were designed in this experiment. In control 1 (CK1) taro seedlings were directly planted in rows without mulching with film or straw, and fertilizer combined with soil was applied around the plant at the taro expansion stage. In control 2 (CK2) seedlings were covered with black mulching film. At the taro expansion stage, the mulched film was removed and fertilizer combined with soil was applied around the plant. Treatment $(\mathrm{T})$ seedlings were directly planted in rows, and fertilizer combined with rice straw (untreated) mulching at $15,000 \mathrm{~kg} /$ ha was applied on the row surface at the taro expansion stage (Figure 1B).

Four plots were designed in a plastic tunnel and three treatments were randomly arranged in the four plots. The area of the plot and the randomized block trial experimental design were the same as in the wheat straw mulching experiment (Figure 1C).

For all treatments, $150 \mathrm{~kg} / \mathrm{ha}$ of urea and $22.5 \mathrm{t} /$ ha of rape seed cake were applied as a base fertilizer on 3 April 2019. The planting rows were prepared, and seedlings were transplanted on 20 April 2019. The planting pattern in the rice straw mulching experiment 
was the same as the wheat straw mulching experiment. In the CK1 and CK2 treatments, $30 \mathrm{~kg}$ of ternary compound fertilizer and $3.75 \mathrm{t} / \mathrm{ha}$ of rape seed cake were applied on 24 June 2019. The $T$ treatment received straw mulching and fertilization on the same day. The taro was harvested on 10 November 2019 (Figure 2B).

\subsection{Soil Sampling}

In each plot, five soil samples were collected by the S-type sampling method and mixed (Figure 1D). In the wheat straw mulching experiment, sampling was carried out on 4 May 2019 (before planting) and 4 December 2019 (after harvest). The soil samples were taken at depths of $0-10 \mathrm{~cm}$ and $10-20 \mathrm{~cm}$, respectively. In the rice straw mulching experiment, sampling was performed on 2 April 2019 (before planting) and 10 November 2019 (after harvest). Due to the deeper plowing layer, the soil samples were taken from the 0-10 cm, 10-20 cm, 20-30 cm and 30-40 cm layers, respectively (Figure 2B).

For each plot, a soil sample of $100 \mathrm{~g}$ was collected, the crushed straw and plant roots were removed, $5 \mathrm{~g}$ of fresh soil samples were retained in a refrigerator for enzyme assay, and the remainder of the samples were air dried and ground for other testing.

\subsection{Determination of Soil Chemical Properties}

Ground soil samples were passed through a $2 \mathrm{~mm}$ sieve to determine selected soil chemical properties. For soil organic carbon (SOC) determination soil samples were further passed through a $0.5 \mathrm{~m}$ sieve. SOC was determined by wet oxidation of soil samples with acid dichromate $\left(\mathrm{Cr}_{2} \mathrm{O}\right)$ following the Walkey and Black method [21]. Soil alkali hydrolyzable N (SAN) content was quantified by the method of Roberts et al. [22]. Briefly, $5 \mathrm{~g}$ samples of soil were distilled with $10 \mathrm{~mol} \mathrm{~L}^{-1} \mathrm{NaOH}$. Boric acid $\left(40 \mathrm{~g} \mathrm{~L}^{-1}\right)$ was used to absorb the liberated $\mathrm{NH}_{3}$ using the method of direct steam distillation. SAN content was quantified by conductometric titration [23]. The soil rapid available phosphorus (SAP) contents were determined by Mehlich 3 extraction and the molybdenum-antimonyresistance colorimetric method [24]. The soil rapid available potassium (SAK) content was determined by Mehlich 3 extraction and flame photometry [25].

\subsection{Determination of Enzymatic Activities}

Soil sucrase activity was determined by 3,5-dinitrosalicylic acid colorimetry and

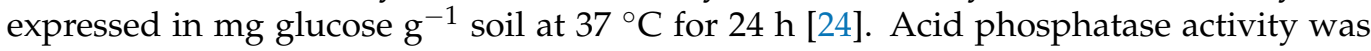
determined according to Tabatabai [26] method after soil incubation with p-nitrophenyl phosphate disodium and measuring the p-nitrophenol (PNF) absorbance at $400 \mathrm{~nm}$. For each soil sample, measurements were repeated three times and the average value was taken for analysis.

\subsection{Statistical Analysis}

The data were processed and analyzed by Excel 2010 (Microsoft, Washington, WA, USA) and SPSS 19.0 (IBM SPSS, Armonk, NY, USA). The results were analyzed by Analysis of Variance (ANOVA) with SPSS19.0.

\section{Result}

\subsection{Decomposition Rate of Crop Straws}

The results of the wheat straw mulching experiment showed that short straw decomposed completely (Figure 3A,B), while the decomposition rates of the long straw under the $\mathrm{L}$ and $\mathrm{H}$ treatments were $94 \%$ and $96 \%$ (Figure 3C,D), respectively, which indicates that most of the straw had decomposed. Under the experimental conditions, most rice straw also decomposed, and the decomposition rate was $74 \%$ (Figure $3 \mathrm{E}$ ), but compared with wheat straw, the decomposition rate was relatively low. 
A

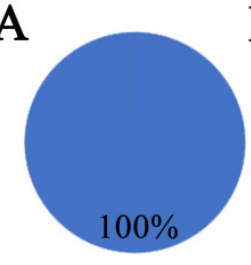

Short:L
B

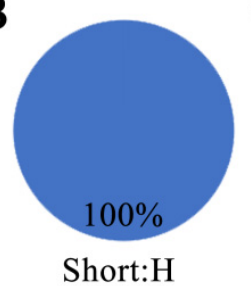

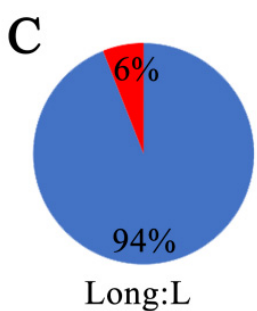

Long:L
D

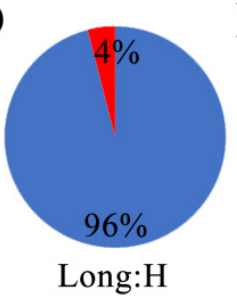

$\mathrm{E}$

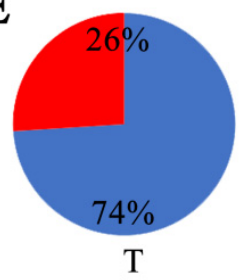

F

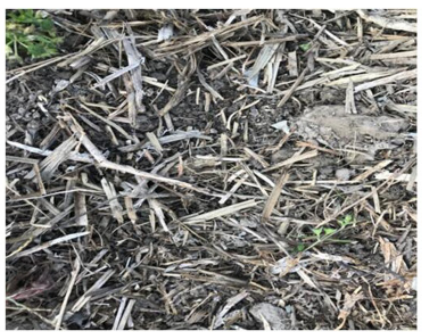

G

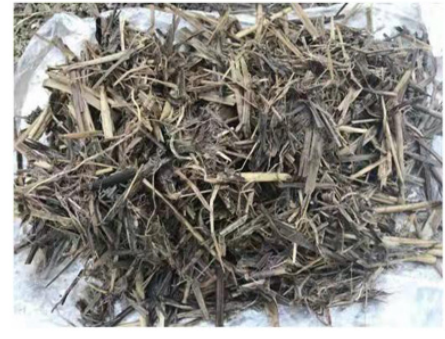

Figure 3. Decomposition of straw in the field. (A-E) Straw decomposition rates of different mulching treatments. Short: $10 \mathrm{~cm}$ wheat straw by mechanical cutting. Long: wheat straw without any treatment. L and H: wheat straw mulching treatments (e.g., L, 11,250 kg/ha and H, 18,750 kg/ha). T: rice straw mulching treatment $(\mathrm{T}, 15,000 \mathrm{~kg} / \mathrm{ha})$. (F) Remaining straw after harvest; (G) Collected remaining straw for assay.

\subsection{Effects of Different Wheat Straw Mulching Treatments on Taro Yields}

The results showed that after 7 months of wheat straw mulching, both the $\mathrm{L}$ and $\mathrm{H}$ treatment showed notable yield increases compared with the CK treatment, and the $\mathrm{H}$ was significantly higher than the L. For the same amount of straw, the yield of short straw mulching was higher than that of long straw mulching (Table 2). The results suggest that the wheat straw may release abundant nutrients during decomposition, which increases the taro yields. The decomposed straw in the $\mathrm{H}$ and short straw treatments may release more nutrients within the cropping period and have a greater effect on yield increases.

Table 2. Changes in the total taro yields under different wheat straw mulching treatments.

\begin{tabular}{ccc}
\hline & \multicolumn{2}{c}{ Total Yield of Taro (kg/ha) } \\
\hline Treatment & Short straw & Long straw \\
CK & $18,231 \pm 332^{\mathrm{c}}$ & \\
L & $19,281 \pm 216^{\mathrm{b}}$ & $18,403 \pm 214^{\mathrm{c}}$ \\
H & $20,642 \pm 138^{\mathrm{a}}$ & $20,243 \pm 125^{\mathrm{a}}$ \\
Straw size & $*$ & \\
Straw amount & $*$ & \\
Size $\times$ Amount & NS & \\
\hline
\end{tabular}

Note: L, 11,250 kg/ha and H, 18,750 kg/ha. Data are means $\pm S D(n=3)$. Different lowercase letters within a column indicate significant differences $(p<0.05)$ among different treatments. ${ }^{*} p<0.05$ versus the long straw control, Student's $t$-test. NS: nonsignificant.

\subsection{Effects of Wheat Straw Mulching on Soil Nutrients}

For the $0-10 \mathrm{~cm}$ soil layer, the SOC contents increased compared with the CK treatment, and the SOC contents in the $\mathrm{H}$ treatment were significantly higher than those in the $\mathrm{L}$ treatment after covering with short straw. After covering with long straw, the change trend of the SOC contents was consistent with that of short straw mulching, but the SOC contents were significantly lower than those covered with short straw. The trend of the SOC contents in the 10-20 cm soil layer was similar to that in the $0-10 \mathrm{~cm}$ soil layer, but there were no significant differences in the SOC contents under the different treatments. Overall, the 
SOC contents in the $0-10 \mathrm{~cm}$ soil layer were higher than those in the $10-20 \mathrm{~cm}$ soil layer (Figure 4A).

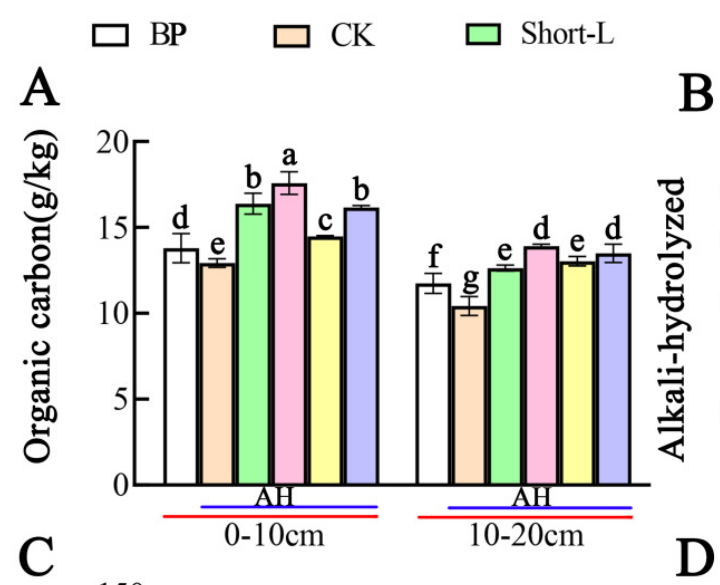

B
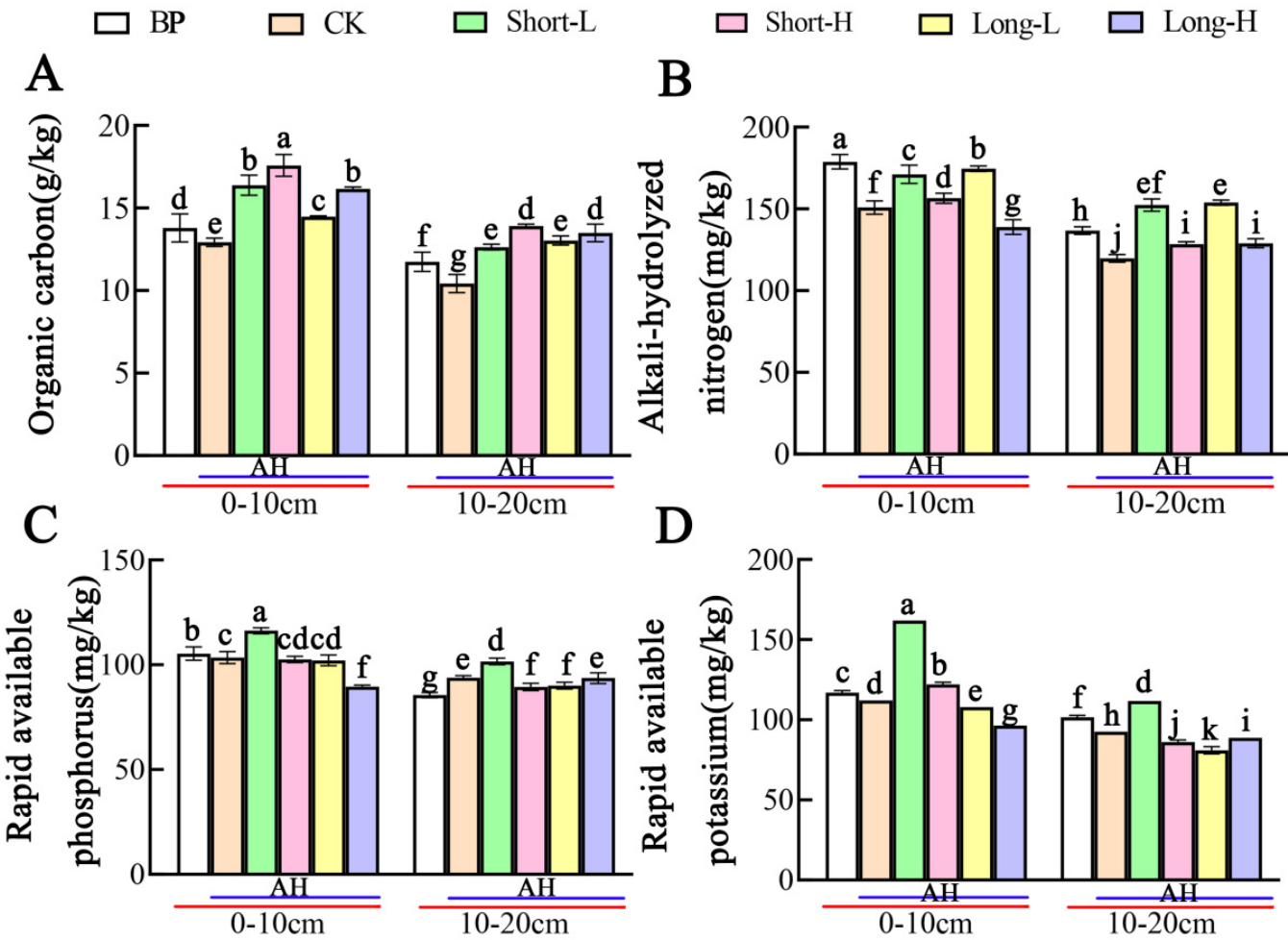

Figure 4. Variation trends of the nutrient contents in different soil layers under different wheat straw mulching treatments. Short: $10 \mathrm{~cm}$ wheat straw by mechanical cutting. Long: wheat straw without any treatment. $\mathrm{BP}$, before planting; $\mathrm{AH}$, after harvest; $\mathrm{CK}$, soil layer without any treatment; L, 11,250 kg/ha straw mulching; $\mathrm{H}, 18,750 \mathrm{~kg} /$ ha straw mulching. (A), the organic carbon of the soil; (B), the alkali-hydrolyzed nitrogen of the soil; (C), the rapid available phosphorus of the soil; (D), the rapid available potassium of the soil. Data are means $\pm S D(n=3)$. The different lowercase letters in the figure indicate significant differences between the different treatments based on the bidirectional ANOVA tests $(p<0.05)$.

For the $0-10 \mathrm{~cm}$ soil layer, the SAN contents increased compared with the CK in both the $\mathrm{L}$ and $\mathrm{H}$ treatments, and the SAN contents in the $\mathrm{L}$ were significantly higher than those in the $\mathrm{H}$ treatment after covering with short straw. The change trend of the SAN contents after long straw covering was consistent with that of short straw covering. The SAN contents in the L after short straw mulching were lower than those of long straw mulching, while they were higher than those in the $\mathrm{H}$ treatment after covering with short straw. The trend of the SAN contents in the 10-20 cm layer was similar to that of the $0-10 \mathrm{~cm}$ soil layer, but there were no significant differences in the SAN contents for the different treatments after they were covered with different straw lengths. Overall, the SAN contents in the $0-10 \mathrm{~cm}$ soil layer were higher than those in the $10-20 \mathrm{~cm}$ soil layer (Figure $4 \mathrm{~B}$ ).

For the $0-10 \mathrm{~cm}$ soil layer, the SAP contents in the soil increased compared with those of the $\mathrm{CK}$ in the $\mathrm{L}$ treatment after covering with short straw. However, there were no significant differences in the SAP contents between the $\mathrm{CK}$ and $\mathrm{H}$ treatments. The trend of the SAP contents after long straw mulching was similar to that of short straw mulching, but the contents were lower in long straw mulching. The general SAP trend in the 10-20 cm soil layer was similar to that in the $0-10 \mathrm{~cm}$ soil layer, but the SAP contents in the L treatment decreased more notably compared with those in the CK after long straw mulching (Figure 4C).

For the 0-10 cm soil layer, the SAK levels increased significantly compared with the $\mathrm{CK}$ in both the $\mathrm{L}$ and $\mathrm{H}$ treatments after short straw mulching. After covering with long 
straw, the SAK contents decreased significantly compared with the CK and were in the order of $\mathrm{CK}>\mathrm{L}>\mathrm{H}$. This may be due to the different taro yields under different treatments, since crops with higher yields should absorb more SAK from the soil. The general trend of the SAK contents in the 10-20 cm soil layer was similar to that in the $0-10 \mathrm{~cm}$ soil layer, but after covering with long straw, the SAK contents decreased in the order of $\mathrm{CK}>\mathrm{H}>\mathrm{L}$ (Figure 4D).

\subsection{Effects of Wheat Straw Mulching on Soil Enzyme Activities}

Soil sucrase activities decreased significantly after taro planting. In the $0-10 \mathrm{~cm}$ soil layer, the soil sucrase activities in both $\mathrm{L}$ and $\mathrm{H}$ treatments increased significantly compared with the CK treatment, and those for the L treatment were significantly higher than those for the $\mathrm{H}$ treatment after covering with short straw. After long straw mulching, the soil sucrase activities increased in the order of $\mathrm{CK}=\mathrm{L}<\mathrm{H}$. The sucrase activity trend in the 10-20 cm soil layer was similar, but the levels were generally higher than that in the $0-10 \mathrm{~cm}$ soil layer (Figure 5A).

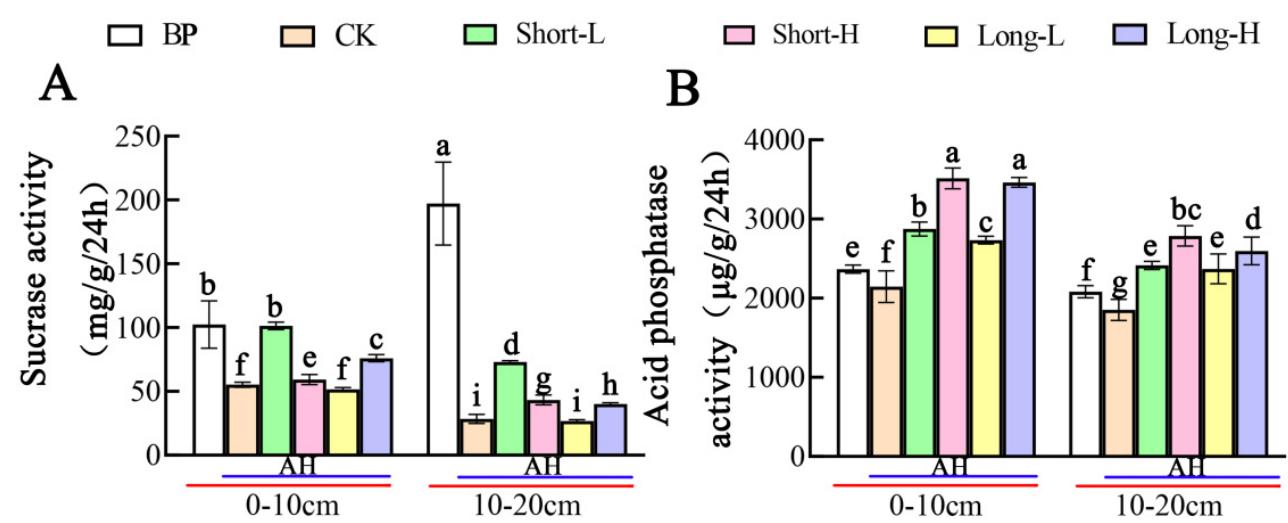

Figure 5. Variation trends of enzyme activities in different soil layers under different straw mulching treatments. Short, $10 \mathrm{~cm}$ wheat straw by mechanical cutting; Long, wheat straw without any treatment. $\mathrm{BP}$, before planting; $\mathrm{AH}$, after harvest; $\mathrm{CK}$, soil layer without any treatment; L, 11,250 kg / ha straw mulching; H, 18,750 kg/ha straw mulching. (A), the sucrase activity of the soil; (B), the acid phosphatase activity of the soil. Data are means \pm SD $(n=3)$. The different lowercase letters in the figure indicate significant differences between the different treatments based on the bidirectional ANOVA tests $(p<0.05)$.

The soil acid phosphatase activities increased to a certain extent after planting taro. In the $0-10 \mathrm{~cm}$ soil layer, the soil acid phosphatase activities in both the $\mathrm{L}$ and $\mathrm{H}$ treatments increased significantly compared with the CK treatment, and those for the $\mathrm{H}$ treatment were significantly higher than for the $\mathrm{L}$ treatment after covering with short straw. The trend for the soil acid phosphatase activities after covering with long straw was consistent with that of short straw, and there were no significant differences between them. The variation trend for the acid phosphatase activities in the 10-20 cm soil layer was consistent with that of the $0-10 \mathrm{~cm}$ soil layer, but the acid phosphatase activities in the $0-10 \mathrm{~cm}$ soil layer were higher than those in the 10-20 cm soil layer (Figure 5B).

\subsection{Effect of Rice Straw Mulching on Taro Yields}

As shown in Table 3, the yield after the T treatment was $27,086.7 \mathrm{~kg} / \mathrm{ha}$, which was higher than that of the CK1 treatment and much higher than that of the CK2 treatment. Therefore, it can be confirmed that rice straw mulching can significantly increase the yields of taro in one season. Taro yield was lower of CK2 than that of CK1, indicating film mulch is not a suitable technology to substitute traditional ridging. 
Table 3. Changes in total taro yields under different straw mulching treatments.

\begin{tabular}{cc}
\hline Different Treatments & Total Output kg/ha \\
\hline CK1 & $25,518 \pm 385^{\mathrm{b}}$ \\
CK2 & $23,102 \pm 425^{\mathrm{c}}$ \\
T & $27,086 \pm 980^{\mathrm{a}}$
\end{tabular}

Note. CK1: taro seedlings were directly planted on the rows without mulching with film or straw, and the fertilizer combined with soil was applied around the plant at the taro expansion stage. CK2: seedlings were covered with black mulching film. At the taro expansion stage, the mulched film was removed, and the fertilizer combined with soil was applied around the plant. T, seedlings were directly planted in the rows, and fertilizer combined with rice straw mulching at $15,000 \mathrm{~kg} / \mathrm{ha}$ was applied on the row surface at the taro expansion stage. Data are means $\pm S D(n=3)$. Different lowercase letters within a column indicate significant differences $(p<0.05)$ between different treatments.

\subsection{Effects of Rice Straw Mulching on the Soil Nutrients}

After planting taro, there were no significant differences in the SOC levels between the CK1 and CK2 treatments in the $0-10 \mathrm{~cm}$ soil depth layer, while the SOC contents increased significantly compared with the control, which indicated that rice straw mulching was beneficial to increasing the SOC contents. The SOC contents in the $0-10 \mathrm{~cm}$ soil layer were higher than those at other soil layers; the deeper the soil layer, the lower the SOC content (Figure 6A).
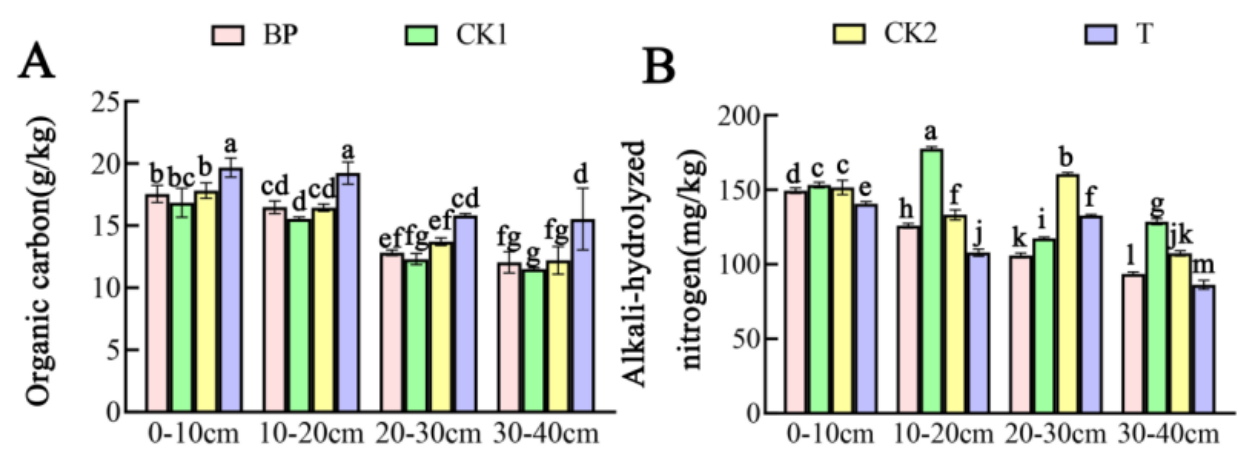

C

D
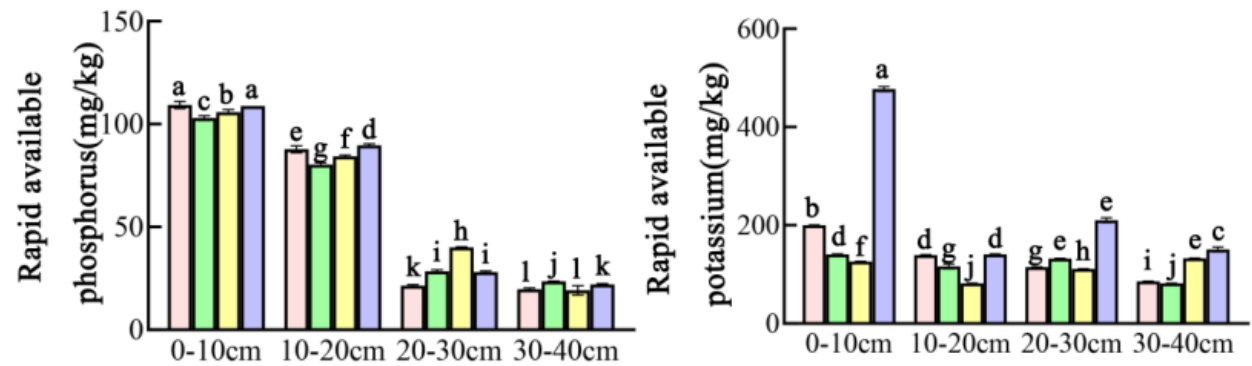

Figure 6. Trends of the nutrient contents at different soil layers under different rice straw mulching treatments. $\mathrm{BP}$, before planting taro; $\mathrm{AH}$, after harvest. $\mathrm{CK} 1$ : taro seedlings were directly planted in the rows without mulching with film or straw, and fertilizer combined with soil was applied around the plant at the taro expansion stage. CK2: seedlings were covered with black mulching film. At the taro expansion stage, the mulched film was removed and fertilizer combined with soil was applied around the plant. T: seedlings were directly planted on the rows, the fertilizer combined with rice straw mulching at $15,000 \mathrm{~kg} /$ ha was applied on the row surface at the taro expansion stage. (A), the organic carbon of the soil; (B), the alkali-hydrolyzed nitrogen of the soil; (C), the rapid available phosphorus of the soil; (D), the rapid available potassium of the soil. Data are means \pm SD $(n=3)$. The different lowercase letters in the figure indicate significant differences between the different treatments based on bidirectional ANOVA tests $(p<0.05)$.

For the $0-10 \mathrm{~cm}$ soil layer, there were no significant differences in the SAN contents between the CK1 and CK2 treatments, while the SAN contents decreased significantly in 
the T treatment compared with the controls. For the $10-20 \mathrm{~cm}$ soil layer, the SAN contents under the CK1 treatment were significantly higher than those of the other treatments and the contents for the $\mathrm{T}$ treatment were the lowest, which may be related to the large amount of $\mathrm{N}$ that was fixed by straw decomposition. For the $20-30 \mathrm{~cm}$ soil layer, the contents of SAN decreased in the order of CK2 > T > CK1, which may be because plastic film mulching reduced the loss and volatilization of $\mathrm{N}$. The SAN patterns among three treatments in the 30-40 cm layer were consistent with those in the 10-20 cm layer. However, in general, the SAN contents in the $0-10 \mathrm{~cm}$ layer were slightly higher than those at other soil depths (Figure 6B).

For the $0-10 \mathrm{~cm}$ soil layer, the SAP contents decreased in the order of T $>C K 2>C K 1$. The overall change trend for the SAP contents in the 10-20 cm layer was consistent with that in the $0-10 \mathrm{~cm}$ soil layer, but the contents were lower than those in the $0-10 \mathrm{~cm}$ layer. Compared with the 0-20 cm layer, the SAP contents in the 20-40 cm layer decreased linearly. In the 20-30 cm soil layer, the SAP contents decreased in the order of CK2 >CK1 $>$ T, while for the 30-40 cm layer, the contents decreased in the order of CK1 > T > CK2. Overall, it was obvious that with increasing soil depth, the SAP contents were lower (Figure 6C).

For the $0-10 \mathrm{~cm}$ soil layer, the SAK contents increased in the order of $\mathrm{CK} 2<\mathrm{CK} 1<\mathrm{T}$, and their contents increased sharply under the $\mathrm{T}$ treatment. The overall trend for the SAK contents in the 10-30 cm soil layer was consistent with that in the $0-10 \mathrm{~cm}$ soil layer, and the contents in the 10-30 cm soil layer were lower than those in the $0-10 \mathrm{~cm}$ soil layer. For the 30-40 cm soil layer, the SAK contents increased in the order of CK1 $<$ CK $2<\mathrm{T}$. In general, the $\mathrm{T}$ treatment had a positive effect on the increase in SAK, and the contents in the $0-10 \mathrm{~cm}$ soil layer were significantly higher than those at other soil depths (Figure 6D).

\subsection{Effects of Rice Straw Mulching on the Soil Enzyme Activities}

Soil sucrase activities decreased after taro planting. For the $0-10 \mathrm{~cm}$ soil layer, there were no significant differences among the three treatments, but the sucrase activities increased in the $\mathrm{T}$ treatment compared with the CK2 treatment, which may be because straw mulching promoted an increase in sucrase activity. The change trend for the sucrase activity in the $10-40 \mathrm{~cm}$ soil layer was consistent with that in the $0-10 \mathrm{~cm}$ soil layer, and the sucrase activities were higher after the $\mathrm{T}$ treatment. Compared with each soil depth, in the shallow soil layers, the sucrose activities were relatively high (Figure 7A).

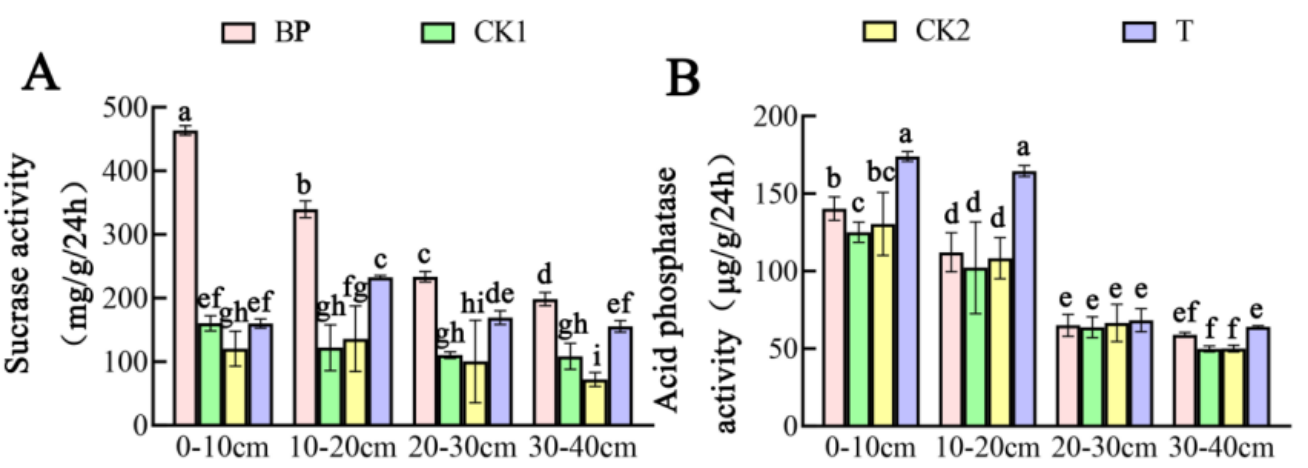

Figure 7. Trends of enzyme activities at different soil layers under different rice mulching treatments. $\mathrm{BP}$, before planting taro; $\mathrm{AH}$, after harvest. CK1: taro seedlings were directly planted in the rows without mulching with film or straw, and fertilizer combined with soil was applied around the plant at the taro expansion stage. CK2: seedlings were covered with black mulching film. At the taro expansion stage, the mulched film was removed and fertilizer combined with soil was applied around the plant. T: seedlings were directly planted on the rows, the fertilizer combined with rice straw mulching at $15,000 \mathrm{~kg} /$ ha was applied on the row surface at the taro expansion stage. (A), the sucrase activity of the soil; (B), the acid phosphatase activity of the soil. Data are means $\pm \operatorname{SD}(n=3)$. The different lowercase letters in the figure indicate significant differences between the different treatments based on bidirectional ANOVA tests $(p<0.05)$. 
Soil acid phosphatase activities increased after planting taro. For the $0-10 \mathrm{~cm}$ soil layer, there were no significant differences in the soil acid phosphatase activities between the CK1 and CK2 treatments, but the soil acid phosphatase activities increased significantly under the T treatment, which indicates that straw mulching was beneficial for improving the soil acid phosphatase activities. The change trend for the acid phosphatase activities in the 10-40 cm soil layer was consistent with that in the $0-10 \mathrm{~cm}$ soil layer; the deeper the soil depth, the lower the acid phosphatase activity (Figure 7B).

\section{Discussion}

Straw returning can be divided into two main methods: mulching returning and tillage returning [27]. The effects of the two straw return methods on the soil physical and chemical properties are distinct. Since straw is integrated into the soil with tillage return, the soil physical and chemical properties should be profoundly affected. Some studies have shown that tillage returning to can effectively reduce the soil bulk density, increase soil porosity, and promote the formation of granular soil structures [28-31]. In addition, straw is rich in organic material, N, P, K and other nutrients, which can effectively supplement these components in the soil after returning to the field [31-34]. However, the effects of straw mulching return are different since the straw is not directly mixed into the soil. Some studies have shown that mulching straw in soil can reduce the evaporation of soil surface moisture [35]. Secondly, because straw provides a water-retaining function, straw mulching is also conducive to the long-term maintenance of the bed surface moisture [36]. In addition, straw mulching can also effectively regulate soil temperature. In general, compared with no mulching, the soil temperature fluctuation after mulching was relatively moderate [37]. In addition, the straw that covers the soil surface decomposes over a long period, and after various components infiltrate into the soil layer, it can play a similar role as that of tillage return [31,38]. Our results showed that under humid conditions, wheat straw decomposed almost completely, and rice straw decomposed by nearly $74 \%$ within 7 months. Therefore, the effects of mulching return can be obtained in one crop season.

The decomposition rates of straw are related to the compositions, temperatures, humidities and other factors. In our study, the decomposition rates of wheat straw were higher than those of rice straw, which might be caused by the differences in the carbon/nitrogen ratios and lignin and polyphenol contents between the two kinds of straws [39]. Therefore, wheat straw is more suitable for hygrocolous vegetables with short growth periods. According to other straw mulching experiments under conventional conditions, the wet soil surface can accelerate straw decomposition [40], which was confirmed in our research. In addition, the decomposition of straw was affected by the soil temperature and straw crushing degree. The soil microbial activities were affected by soil temperature, and resulted in greater soil hydrolase accumulations. Krishnan et al. [41] found that the activities of the decomposition agent and soil enzymes were maximized between $30^{\circ} \mathrm{C}$ and $35^{\circ} \mathrm{C}$. In this study, straw mulching also increased soil surface temperature to promote straw decomposition. In addition, the results of this study showed that the decomposition rate of truncated straw was higher than that of untreated straw. Therefore, environmental conditions that are favorable for straw decomposition should be created in the application of straw mulching to improve straw use efficiency during the season and reduce the negative effect of straw return.

The effect of straw return on the contents of $\mathrm{N}, \mathrm{P}, \mathrm{K}$ and other nutrients were quite complicated. On the one hand, various nutrients were released by different processes during straw decomposition, while $\mathrm{N}$ was fixed at the initial stage of degradation [42]. On the other hand, straw mulching of the soil surface prevented water from evaporating and slowed down the movement of ions to the soil surface [43]. At the same time, straw mulching increased the soil organic matter content and effectively improved the soil water and fertilizer retention abilities [44,45]. In addition, crops had different yields and absorbed different amount of nutrients, which also has a subtle influence on the soil nutrient level. In this study, the SAN levels in the $\mathrm{H}$ treatment were lower than those in the L treatment in 
the wheat straw mulching experiment, and the decrease of SAN in a specific period may be due to the large amount of straw that was used in the $\mathrm{H}$ treatment and the large amount of $\mathrm{N}$ fixation that was present during straw decomposition (Figure 4B). N consumption during straw decomposition also occurred in the rice straw study (Figure 6B). The SAP levels in the $\mathrm{H}$ treatment were lower than those in the $\mathrm{L}$ treatment, which may be because the SAP was released slowly, while the taro yields were higher, and the amounts of absorbed $\mathrm{P}$ were greater under the $\mathrm{H}$ treatment (Figure $4 \mathrm{C}$ ). The SAK levels were lower under long straw mulching than under short straw mulching, which indicated that the differences in $\mathrm{K}$ release between long straw and short straw were great (Figure 4D). In general, our research showed that covering the soil surface with straw could release nutrients to the soil during the decomposition process, which improved crop yields. Compared with other straw mulching experiments in which the improvement effects of soil nutrient were always observed after several years of mulching [46], the significant increase of P and K occurred in the current season in our study. In addition, some studies have shown that straw is rich in carbon and that large amounts of $\mathrm{CO}_{2}$ would be released during decomposition, which could increase the $\mathrm{CO}_{2}$ concentrations and photosynthesis in the field and promote plant growth during mulching. This might be another factor that contributed to increasing the crop yields in the field [47].

Soil enzymes such as phosphatase and sucrase provided information about the capacity of soil biochemistry reactions and were important indicators to determine soil fertility and microbial activity and diversity [48]. Organic P in compounds is hydrolyzed to inorganic P for plant use by phosphatase [49]. Sucrose is hydrolyzed to glucose and fructose by sucrase and provides materials for plant and soil microbial metabolisms [50]. Abundant reaction substrates for soil enzymes and the main source of soil enzymes were provided by straw mulching. Therefore, straw mulching can promote the production and creation of inducible enzymes, which improves the soil environment where these catalytic reactions occur [51,52]. There have been many reports on the effects of straw return on soil enzyme activities. In general, straw return could improve the activities of various soil enzymes $[53,54]$. Similar to other effects of straw mulching, the improvement of soil enzyme activities would be observed only after several years after mulching under normal conditions [29]. However, our results showed that both wheat and rice straw mulching on wet rows could increase the sucrase and phosphatase activities in the soil to similar levels as those observed under tillage mulching [29].

\section{Conclusions}

In our study, almost all wheat straw and $74 \%$ of rice straw decomposed in 7 months during growing season when mulched on the wet soil surface. Straw mulching significantly increased the taro yield, and several soil chemical properties, including the levels of SOC, soil rapid available nitrogen, phosphorus, potassium, and the activities of sucrase and phosphatase. We conclude that the row-surface straw mulching technology in wet crop production could not only improve the crop yields and soil chemical properties in the protected facility but could also consume considerable straw (wheat: 14,250 kg/ha, rice: $11,100 \mathrm{~kg} / \mathrm{ha})$. This process can be popularized and applied in other areas with similar conditions.

Author Contributions: Conceptualization, M.M. and J.J.; methodology, J.Q., Y.Z. and H.Z.; validation, J.Q., Y.Z. and H.Z.; formal analysis, H.D.; investigation, J.Q., Y.Z. and H.Z.; resources, J.J.; data curation, Z.Z. (Zihui Zhu); writing-original draft preparation, Z.Z. (Zihui Zhu); writing-review and editing, M.M.; visualization, Z.Z. (Zihui Zhu); supervision, H.D. and Z.Z. (Zhiping Zhang); All authors have read and agreed to the published version of the manuscript.

Funding: This research was funded by [Jiangsu Modern Agricultural (Vegetable) Industrial Technology System] grant number [JATS [2018] 309, JATS [2019] 455, JATS [2020] 442] and [Jiangsu Agriculture science and Technology Innovation Fund] grant number [CX (19) 3034]. 
Acknowledgments: This research was supported by Jiangsu Modern Agricultural (Vegetable) Industrial Technology System (JATS [2018] 309, JATS [2019] 455, JATS [2020] 442) and Jiangsu Agriculture science and Technology Innovation Fund (CX (19) 3034).

Conflicts of Interest: The authors declare no conflict of interest.

\section{References}

1. Zhou, W.; Ma, T.T.; Chen, L.; Wu, L.H.; Luo, Y.M. Application of catastrophe theory in comprehensive ecological security assessment of plastic greenhouse soil contaminated by phthalate esters. PLoS ONE 2018, 13, e0205680. [CrossRef] [PubMed]

2. Lupatini, M.; Korthals, G.W.; de Hollander, M.; Janssens, T.K.S.; Kuramae, E.E. Soil microbiome is more heterogeneous in organic than in conventional farming system. Front. Microbiol. 2017, 7, 02064. [CrossRef] [PubMed]

3. Ju, X.T.; Xing, G.X.; Chen, X.P.; Zhang, S.L.; Zhang, L.J.; Liu, X.J.; Cui, Z.L.; Yin, B.; Christie, P.; Zhu, Z.L.; et al. Reducing environmental risk by improving $\mathrm{N}$ management in intensive Chinese agricultural systems. Proc. Natl. Acad. Sci. USA 2009, 106, 3041-3046. [CrossRef] [PubMed]

4. Yin, H.J.; Zhao, W.Q.; Li, T.; Cheng, X.Y.; Liu, Q. Balancing straw returning and chemical fertilizers in China: Role of straw nutrient resources. Renew. Sustain. Energy Rev. 2018, 81, 2695-2702. [CrossRef]

5. Hu, W.Y.; Zhang, Y.X.; Huang, B.; Teng, Y. Soil environmental quality in greenhouse vegetable production systems in eastern China: Current status and management strategies. Chemosphere 2017, 170, 183-195. [CrossRef]

6. Duncan, A.J.; Samaddar, A.; Blummel, M. Rice and wheat straw fodder trading in India: Possible lessons for rice and wheat improvement. Field Crop. Res. 2020, 246, 107680. [CrossRef]

7. Hou, R.; Hu, J.; Wang, Y.; Wei, H.; Gao, M.T. Simultaneous production of cellulase and ferulic acid esterase by penicillium decumbens with rice straw as the sole carbon source. J. Biosci. Bioeng. 2020, 129, 276-283. [CrossRef]

8. Paul, A.S.; Panwar, N.L.; Salvi, B.L.; Jain, S.; Sharma, D. Experimental investigation on the production of bio-oil from wheat straw. Energy Sources Part A 2020, 6, 1-16. [CrossRef]

9. Gosens, J.; Lu, Y.; He, G.Z.; Bluemling, B.; Beckers, T.A. Sustainability effects of household-scale biogas in rural China. Energy Policy 2013, 54, 273-282. [CrossRef]

10. Sun, D.Q.; Bai, J.F.; Qiu, H.G.; Cai, Y.Q. Impact of government subsidies on household biogas use in rural China. Energy Policy 2014, 73, 748-756. [CrossRef]

11. Liu, W.; Lund, H.; Mathiesen, V.B.; Zhang, X.L. Potential of renewable energy systems in China. Appl. Energy 2011, 88, 518-525. [CrossRef]

12. Zhao, X.; Wang, J.W.; Wang, S.Q.; Xing, G.X. Successive straw biochar application as a strategy to sequester carbon and improve fertility: A pot experiment with two rice/wheat rotations in paddy soil. Plant Soil 2014, 378, 279-294. [CrossRef]

13. Zhang, D.; Yan, M.; Niu, Y.; Liu, X.; Zwieten, L.V.; Chen, D.; Bian, R.I.; Cheng, K.; Li, L.Q.; Joseph, S.; et al. Is current biochar research addressing global soil constraints for sustainable agriculture? Agric. Ecosyst. Environ. 2016, 226, 25-32. [CrossRef]

14. Sun, D.Q.; Ge, Y.; Zhou, Y.H. Punishing and rewarding: How do policy measures affect crop straw use by farmers? An empirical analysis of Jiangsu Province of China. Energy Policy 2019, 134, 110882. [CrossRef]

15. Mourtzinis, S.; Gaska, J.; Diallo, T.; Lauer, J.G.; Conley, S. Legacy effects of three management practices on corn, soybean, and wheat yield. Agron. J. 2018, 110, 418-424. [CrossRef]

16. Zhu, H.; Wang, Z.X.; Luo, X.M.; Song, J.X.; Huang, B. Effects of straw incorporation on Rhizoctonia solani inoculum in paddy soil and rice sheath blight severity. J. Agric. Sci. 2014, 152, 741-748. [CrossRef]

17. Gondim, A.R.D.O.; Puiatti, M.; Ventrella, M.C.; Cecon, P.R. Plasticidade anatomica da folha de taro cultivado sob diferentes condicoes de sombreamento [Leaf plasticity in taro plants under different shade conditions]. Bragantia 2008, 67, 1037-1045. [CrossRef]

18. Ribeiro Pereira, P.; Bertozzi de Aquino Mattos, E.; Nitzsche Teixeira Fernandes Correa, A.C.; Afonso Vericimo, M.; Margaret Flosi Paschoalin, V. Anticancer and immunomodulatory benefits of taro (Colocasia esculenta) corms, an underexploited tuber crop. Int. J. Mol. Sci. 2021, 22, 265. [CrossRef]

19. Kaushal, P.; Kumar, V.; Sharma, H.K. Utilization of taro (Colocasia esculenta): A review. J. Food Sci. Technol. 2015, 52, 27-40. [CrossRef]

20. Nakajima, M.; Cheng, W.G.; Tang, S.R.; Hori, Y.; Yaginuma, E.; Hattori, S.; Hanayama, S.; Tawaraya, K.; Xu, X.K. Modeling aerobic decomposition of rice straw during the off-rice season in an Andisol paddy soil in a cold temperate region of Japan: Effects of soil temperature and moisture. Soil Sci. Plant Nutr. 2016, 62, 90-98. [CrossRef]

21. Dewis, J.; Freitas, F. Physical and chemical method of soil and water analysis. FAO Soils Bull. 1970, 10, 275.

22. Chen, B.L.; Yang, H.K.; Song, W.C.; Liu, C.Y.; Xu, J.; Zhao, W.Q.; Zhou, Z.G. Effect of N fertilization rate on soil alkali-hydrolyzable $\mathrm{N}$, subtending leaf $\mathrm{N}$ concentration, fiber yield, and quality of cotton. Crop J. 2016, 4, 323-330. [CrossRef]

23. Roberts, T.; Ross, W.; Norman, R.; Slaton, N.; Wilson, C. Predicting nitrogen fertilizer needs for rice in Arkansas using alkalinehydrolyzable-nitrogen. Soil Sci. Soc. Am. J. 2011, 75, 1161-1171. [CrossRef]

24. Li, W.H.; Liu, Q.Z. The dynamic characteristics of soil enzyme activity and nematode diversity in replanted strawberry rhizosphere soil. Acta Hortic. 2017, 1156, 235-242. [CrossRef] 
25. Wen, Y.M.; You, J.W.; Zhu, J.; Hu, H.Q.; Gao, J.S.; Huang, J. Long-term green manure application improves soil K availability in red paddy soil of subtropical China. J. Soils Sediments 2020, 21, 63-72. [CrossRef]

26. Tabatabai, M.A.; Bremner, J.M. Use of p-nitrophenyl phosphate for assay of soil phosphatase activity. Soil Biol. Biochem. 1969, 1 , 301-307. [CrossRef]

27. Zhao, J.L.; Wang, X.G.; Zhuang, J.; Cong, Y.J.; Lu, Y.; Guo, M.Z. Fine-crush straw returning enhances dry matter accumulation rate of maize seedlings in northeast China. Agronomy 2021, 11, 1144. [CrossRef]

28. Mizuta, K.; Taguchi, S.; Sato, S. Soil aggregate formation and stability induced by starch and cellulose. Soil Biol. Biochem. 2015, 87, 90-96. [CrossRef]

29. Yang, H.S.; Feng, J.X.; Zhai, S.L.; Dai, Y.J.; Xu, M.M.; Wu, J.S.; Shen, M.X.; Bian, X.M.; Koidec, R.T.; Liu, j. Long-term ditch-buried straw return alters soil water potential, temperature, and microbial communities in a rice-wheat rotation system. Soil Tillage Res. 2016, 163, 21-31. [CrossRef]

30. Xiu, L.Q.; Zhang, W.M.; Sun, Y.Y.; Wu, D.; Meng, J.; Chen, W.F. Effects of biochar and straw returning on the key cultivation limitations of Albic soil and soybean growth over 2 years. Catena 2019, 173, 481-493. [CrossRef]

31. Huang, R.; Lan, M.L.; Liu, J.; Gao, M. Soil aggregate and organic carbon distribution at dry land soil and paddy soil: The role of different straws returning. Environ. Sci. Pollut. Res. 2017, 24, 27942-27952. [CrossRef] [PubMed]

32. Lu, F. How can straw incorporation management impact on soil carbon storage? A meta-analysis. Mitig. Adapt. Strat. Glob. Chang. 2015, 20, 1545-1568. [CrossRef]

33. Cui, Y.F.; Meng, J.; Wang, Q.X.; Zhang, W.M.; Cheng, X.Y.; Chen, W.F. Effects of straw and biochar addition on soil nitrogen, carbon, and super rice yield in cold waterlogged paddy soils of North China. J. Integr. Agric. 2017, 16, 1064-1074. [CrossRef]

34. Zhao, Y.C.; Wang, M.Y.; Hu, S.J.; Zhang, X.D.; Ouyang, Z.; Zhang, G.L.; Huang, B.; Zhao, S.W.; Wu, J.S.; Xie, D.T.; et al. Economicsand policy-driven organic carbon input enhancement dominates soil organic carbon accumulation in Chinese croplands. Proc. Nat. Acad. Sci. USA 2018, 115, 4045-4050. [CrossRef] [PubMed]

35. Yusefi, A.; Farrokhian Firouzi, A.; Aminzadeh, M. The effects of shallow saline groundwater on evaporation, soil moisture, and temperature distribution in the presence of straw mulch. Hydrol. Res. 2020, 51, 720-738. [CrossRef]

36. Cao, J.; Liu, C.; Zhang, W.; Guo, Y. Effect of integrating straw into agricultural soils on soil infiltration and evaporation. Water Sci. Technol. 2012, 65, 2213-2218. [CrossRef] [PubMed]

37. Fan, J.; Gao, Y.; Wang, Q.J.; Sukhdev, S.M.; Li, Y.Y. Mulching effects on water storage in soil and its depletion by alfalfa in the Loess Plateau of northwestern China. Agric. Water Manag. 2014, 138, 10-16. [CrossRef]

38. Lenka, N.K.; Lal, R. Soil aggregation and greenhouse gas flux after 15 years of wheat straw and fertilizer management in a no-till system. Soil Tillage Res. 2013, 126, 78-89. [CrossRef]

39. Tian, G.L.; Brussaard, L.; Kang, B.T. An index for assessing the quality of plant residues and evaluating their effects on soil and crop in the (sub-) humid tropics. Appl. Soil Ecol. 1995, 2, 25-32. [CrossRef]

40. Mando, A.; Brussaard, L. Contribution of termites to the breakdown of straw under Sahelian conditions. Biol. Fertil. Soils 1999, 29, 332-334. [CrossRef]

41. Krishnan, A.; Convey, P.; Gonzalez, M.; Smykla, J.; Alias, S.A. Effects of temperature on extracellular hydrolase enzymes from soil microfungi. Polar Biol. 2018, 41, 537-551. [CrossRef]

42. Wang, W.; Lai, D.Y.F.; Wang, C.; Pan, T.; Zeng, C. Effects of rice straw incorporation on active soil organic carbon pools in a subtropical paddy field. Soil Tillage Res. 2015, 152, 8-16. [CrossRef]

43. Li, J.F.; Zhong, F.F. Nitrogen release and re-adsorption dynamics on crop straw residue during straw decomposition in an Alfisol J. Integr. Agric. 2021, 20, 248-259. [CrossRef]

44. Ghimire, R.; Adhikari, K.R.; Chen, Z.S.; Shah, S.C.; Dahal, K.R. Soil organic carbon sequestration as affected by tillage, crop residue, and nitrogen application in rice-wheat rotation system. Paddy Water Environ. 2012, 10, 95-102. [CrossRef]

45. Johnson, J.M.F.; Novak, J.M.; Varvel, G.E.; Stott, D.E.; Osborne, S.L.; Karlen, D.L.; Lamb, J.A.; Baker, J.; Adler, P.R. Crop residue mass needed to maintain soil organic carbon levels: Can it be determined? BioEnergy Res. 2014, 7, 481-490. [CrossRef]

46. Liu, S.W.; Wang, M.J.; Yin, M.; Chu, G.; Xu, C.M.; Zhang, X.G.; Abliz, N.; Tang, C.X.; Wang, D.Y.; Chen, S. Fifteen years of crop rotation combined with straw management alters the nitrogen supply capacity of upland-paddy soil. Soil Tillage Res. 2022, 215, 105219. [CrossRef]

47. Fan, R.Q.; Zhang, B.H.; Li, J.Y.; Zhang, Z.H.; Liang, A.Z. Straw-derived biochar mitigates $\mathrm{CO}_{2}$ emission through changes in soil pore structure in a wheat-rice rotation system. Chemosphere 2020, 243, 125329. [CrossRef]

48. Burns, R.G.; Deforest, J.L.; Marxsen, J.; Sinsabaugh, R.L.; Stromberger, M.E.; Wallenstein, M.D.; Weintraubg, M.N.; Zoppinih, A. Soil enzymes in a changing environment: Current knowledge and future directions. Soil Biol. Biochem. 2013, 58, 216-234. [CrossRef]

49. Wei, K.; Chen, Z.H.; Zhu, A.N.; Zhang, J.B.; Chen, L.J. Application of 31P NMR spectroscopy in determining phosphatase activities and $\mathrm{P}$ composition in soil aggregates influenced by tillage and residue management practices. Soil Tillage Res. 2014, 138, 35-43. [CrossRef]

50. Yu, P.J.; Liu, S.W.; Han, K.X.; Guan, S.C.; Zhou, D.W. Conversion of cropland to forage land and grassland increases soil labile carbon and enzyme activities in northeastern China. Agric. Ecosyst. Environ. 2017, 245, 83-91. [CrossRef]

51. Pajares, S.; Gallardo, J.F.; Masciandaro, G.; Ceccanti, B.; Etchevers, J.D. Enzyme activity as an indicator of soil quality changes in degraded cultivated Acrisols in the Mexican Trans-volcanic Belt. Land Degrad. Dev. 2011, 22, 373-381. [CrossRef] 
52. Zhang, J.; Bo, G.; Zhang, Z.; Kong, F.; Wang, Y.; Shen, G. Effects of straw incorporation on soil nutrients, enzymes, and aggregate stability in tobacco fields of China. Sustainability 2016, 8, 710. [CrossRef]

53. Ji, B.Y.; Hu, H.; Zhao, Y.L.; Mu, X.Y.; Liu, K.; Li, C.H. Effects of deep tillage and straw returning on soil microorganism and enzyme activities. Sci. World J. 2014, 2014, 451493. [CrossRef] [PubMed]

54. Zhang, Y.L.; Chen, L.J.; Duan, Z.H.; Wu, Z.J.; Sun, C.X.; Wang, J.Y. Change in soil enzymes activities after adding biochar or straw by fluorescent microplate method. Spectrosc. Spectr. Anal. 2014, 34, 455-459. [CrossRef] 